\title{
Atrial myxoma: an unusual aetiology for exertional dyspnoea and palpitation
}

\author{
Omar Gutierrez, ${ }_{1}^{1}$ Richard Michell, ${ }^{2}$ Dale Adler ${ }^{3}$
}

\begin{abstract}
- Additional material is published online only. To view please visit the journal online (http://dx.doi.org/10.1136/ bcr-2017-223341).
\end{abstract}

${ }^{1}$ Harvard Medical School, Boston, Massachusetts, USA 2Department of Pathology, Brigham and Women's Hospital, Boston, Massachusetts, USA ${ }^{3}$ Department of Medicine, Brigham and Women's Hospital, Boston, Massachusetts, USA

\section{Correspondence to} Omar Gutierrez,

jose_gutierrez@hms.harvard. edu

Accepted 24 November 2017

\section{DESCRIPTION}

A 67-year-old woman had recently emigrated from the Dominican Republic where, many years prior, she had been evaluated for 'tachycardias' and had unrevealing monitors. She was well until 6 months prior to admission when she started to experience unpredictable, generally exertional palpitations, dyspnoea and left arm discomfort. There was no history of antecedent anxiety. Examination was notable for a $3 / 6$ systolic murmur heard from apex to base and radiating to the neck that ultimately decreased with Valsalva manoeuvre, consistent with aortic sclerosis that was also seen on her echocardiogram. ECG showed normal sinus rhythm, significant left ventricular hypertrophy with strain and question of a right atrial abnormality. Transthoracic echo, for the murmur, showed a $3 \mathrm{~cm}$ highly mobile atrial mass, sometimes crossing the mitral valve, and aortic sclerosis (online supplementary video 1). Catheterisation showed unremarkable coronary arteries and no vascular attachments to the mass. Cardiac MRI showed a large mobile and multilobulated mass in the left atrium which did not have any resting perfusion (figure 1) or late gadolinium enhancement and was called a thrombus. However, her atrial contribution to filling was excellent (figure 2); thus, thrombosis was excluded. The patient proceeded to surgery.

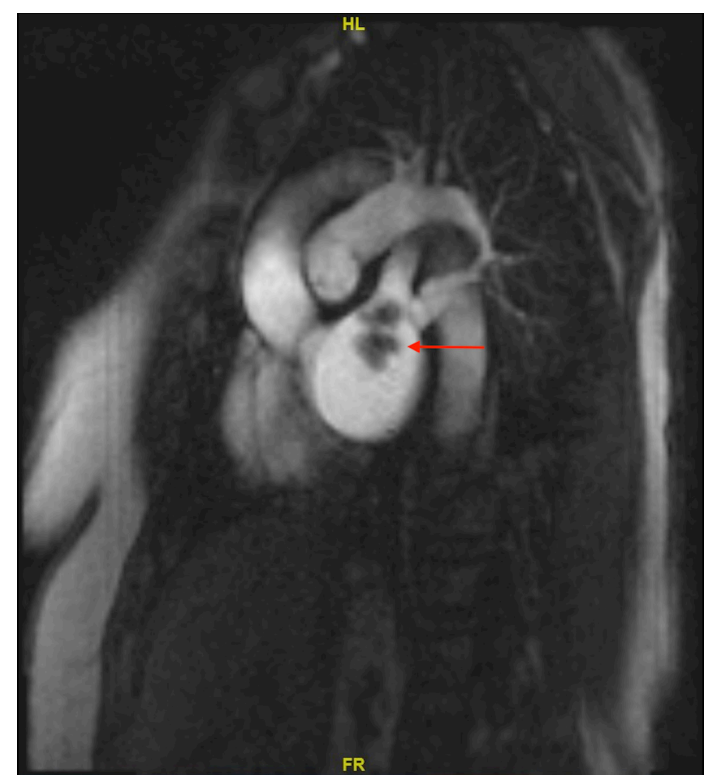

Figure 1 Cardiac MRI characterising large mobile and multilobulated mass in the left atrium (arrow) which did not have any resting perfusion.

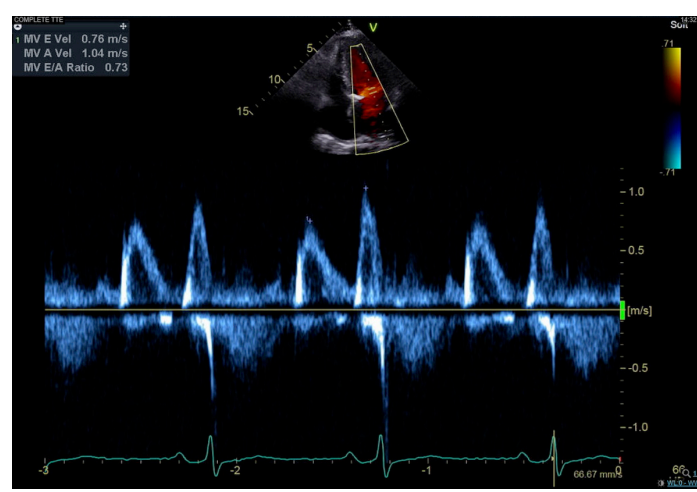

Figure 2 Transthoracic echo with normal mitral inflow.

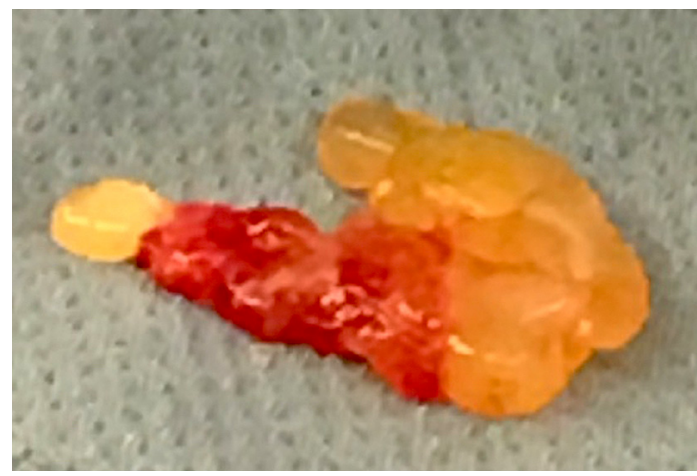

Figure 3 Gross pathology of excised mass depicting a translucent yellow-to-pink, irregular, lobulated gelatinous tissue.

Intraoperative transesophageal echo confirmed the mobile mass, the origin near the left atrial appendage, intermittently prolapsing across

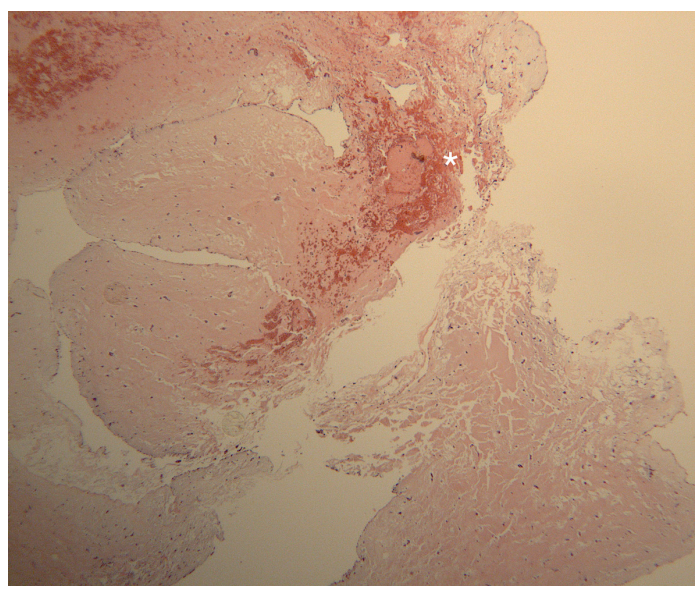

Figure 4 Histopathology showing stellate-shaped cells and abundant myxoid matrix consistent with an atrial myxoma with a surface clot (asterisk). 


\section{Learning points}

- Clinical suspicion and atrial capability were critical considerations, leading to cardiac surgery when imaging suggested a clot.

- Myxomas can have a polypoid and irregular morphology, but surface clot may suggest that the entire mass is simply a clot.

- A mass crossing the mitral valve or blocking the pulmonary veins is an unusual cause of exertional palpitation and sporadic exertional dyspnoea.

the mitral valve (online supplementary video 2). Excision revealed a translucent yellow-to-pink, irregular, lobulated gelatinous tissue (figure 3), and pathology showed stellate-shaped cells and abundant myxoid matrix consistent with an atrial myxoma with a surface clot (figure 4). Myxomas with this morphology, polypoid and prolapsing, have been associated with an increased risk of embolisation. ${ }^{1}$ At 2 weeks, the patient reported resolution of her palpitations and dyspnoea suggesting that her symptoms were perhaps related to the atrial mass intermittently crossing her mitral valve even perhaps blocking a pulmonary vein.

Contributors OG prepared the manuscript draft with important intellectual input from DA and RM. All authors approved the final manuscript.

Competing interests None declared.

\section{Patient consent Obtained.}

Provenance and peer review Not commissioned; externally peer reviewed. (C) BMJ Publishing Group Ltd (unless otherwise stated in the text of the article) 2017. All rights reserved. No commercial use is permitted unless otherwise expressly granted.

\section{REFERENCE}

1 Ha JW, Kang WC, Chung N, et al. Echocardiographic and morphologic characteristics of left atrial myxoma and their relation to systemic embolism. Am J Cardiol 1999;83:1579-82

Copyright 2017 BMJ Publishing Group. All rights reserved. For permission to reuse any of this content visit

http://group.bmj.com/group/rights-licensing/permissions.

BMJ Case Report Fellows may re-use this article for personal use and teaching without any further permission.

Become a Fellow of BMJ Case Reports today and you can:

- Submit as many cases as you like

- Enjoy fast sympathetic peer review and rapid publication of accepted articles

- Access all the published articles

Re-use any of the published material for personal use and teaching without further permission

For information on Institutional Fellowships contact consortiasales@bmjgroup.com

Visit casereports.bmj.com for more articles like this and to become a Fellow 